\title{
Potential uses of Aristotelia chilensis extracts as novel cosmetic materials
}

\author{
Mijung Kim ${ }^{1}$ Seyeon Park ${ }^{2}$ \\ 마키베리 추출물의 화장품 신규 원료로서의 가능성
}

김미정 ${ }^{1} \cdot$ 박세 연 $^{2}$

Received: 23 July 2019 / Accepted: 2 October 2019 / Published Online: 31 December 2019

(C) The Korean Society for Applied Biological Chemistry 2019

\begin{abstract}
The present study aims to investigate the potential applications of Aristotelia chilensis (A. chilensis) extracts as novel cosmetic materials. The total extracts of $A$. chilensis were partitioned into chloroform $\left(\mathrm{CHCl}_{3}\right)$, ethyl acetate (EtOAc), and distilled water (DW) fractions. A. chilensis extracts exhibited no cytotoxicity toward $\mathrm{HaCaT}$ human keratinocyte and B16F10 mouse melanoma cell lines. $\mathrm{CHCl}_{3}, \mathrm{EtOAc}$, and DW extracts reduced oxidative stress, and EtOAc extract was superior to glutathione, a natural human antioxidant positive control. The extracts of $A$. chilensis reduced melanin synthesis in cells treated with $\alpha$-melanocyte-stimulating hormone. The extracts of $A$. chilensis exhibited antibacterial effects toward Staphylococcus aureus (S. aureus), Staphylococcus epidermidis (S. epidermidis), and Pseudomonas aeruginosa (P. aeruginosa). In particular, the EtOAc extract was effective in terms of antibacterial activity against $S$. aureus. In the present study, we identified several potential applications of $A$. chilensis extracts in terms of novel antioxidant and whitening cosmetic materials as well as antibacterial preservatives.
\end{abstract}

Seyeon Park $(\triangle)$

E-mail: Sypark21@dongduk.ac.kr

${ }^{1}$ Department of Health and Cosmetics, Dongduk Women's University, Seoul 02748, Republic of Korea

${ }^{2}$ Department of Applied Chemistry, Dongduk Women's University, Seoul 02748, Republic of Korea

This is an Open Access article distributed under the terms of the Creative Commons Attribution Non-Commercial License (http://creativecommons. org/licenses/by-nc/3.0/) which permits unrestricted non-commercial use, distribution, and reproduction in any medium, provided the original work is properly cited.
Keywords Antibacterial - Antioxidant - Aristotelia chilensis . Melanin synthesis inhibition · Novel cosmetic material

\section{서 론}

천연물들 중에서 항산화능이 가장 우수한 것으로는 과일을 손 꼽을 수 있다. 과일에는 비타민 $\mathrm{C}$, 플라보노이드, 폴리페놀, 카 로티노이드, 토코페롤 등이 함유되어 있어서 free radical로 인 해서 증가되는 산화적 스트레스를 감소시킬 뿐만 아니라 질병 의 예방과 완화에도 영향을 주는 것으로 보고되고 있다[1,2]. 과 일 중에서도 베리류는 한 개의 과실이 작은 열매들의 합체 형 태로 형성된 장과류로서 폴리페놀, 플라보노이드, 안토시아닌 색 소, 유기산 및 탄닌 등을 풍부하게 함유하고 있어서 항산화, 항 염, 항암, 심혈관계 질환의 개선에 도움이 된다고 알려져 있다 [3-5]. 베리에 포함된 중요한 항산화 성분인 안토시아닌은 고등 식물의 꽃, 잎, 줄기, 과실, 뿌리 등의 식물체 부위들에 함유되 어 있는 청색, 자색 및 적색으로 나타내는 색소인데 식물체의 각 부위별 특성에 따라 변형된 구조와 양으로 다르게 발현된다 [6]. 안토시아닌 색소는 뛰어난 항산화성을 지니고 있는 기능성 물질로서 항암, 항염, 항노화 등에 효과가 우수한 것으로 알려 져 있고, 안토시아닌 색소를 포함한 천연 색소들은 항산화 효 과와 함께 항균 작용도 탁월한 것으로 보고되고 있다[7-11]. 안 토시아닌은 3-hydroxyanthocyanidins, 3-deoxy-anthocyanidins, $O$-methylated anthocyanidins, anthocyanidin glycosides, acylated anthocyanins 등의 다양한 형태로 존재하는데 체내에서 생리활 성물질로서의 중요성 때문에 그 효과에 대한 연구가 꾸준히 진 행되고 있다[12].

본 연구에서 사용된 마키베리(Aristotelia chilensis)열매가 열 리는 나무는 칠레, 안데스 산맥의 파타고니아 지역에서 주로 자 생하지만 아르헨티나를 포함한 남아메리카 등지에서도 볼 수 있 
다[13]. 마키베리 나무는 주로 야생에서 볼 수 있기에 그 열매 는 채집의 형태로 수확되는 것으로 알려져 있었으나 과실의 효 능이 알려지면서 최근 세계인에게 관심을 받게 되어 재배지가 증가하고 있는 추세이다[14,15]. 열매는 짙은 보라색으로 직경 이 4-6 mm이고 맛은 단맛과 함께 떫은 맛이 나며 폴리페놀과 안토시아닌 성분을 다량으로 함유하고 있어서 강력한 항산화력 을 가진 베리에 속한다[16,17]. 또한, 26종의 파이토케미컬도 있 는데 이를 통해 각종 해충과 미생물로부터 자신을 보호하며 비 타민 $\mathrm{C}$, 필수지방산, 칼륨 등도 풍부하게 함유하고 있어 다이 어트뿐만 아니라 기미와 주름 등의 피부 노화의 원인이 되는 요소의 활성을 억제한다. 이 외에도 순환계, 면역계에 작용하여 혈액순환을 촉진하며 말초 냉증과 혈색 개선 등에 도움을 주고 염증과 당뇨에도 효과가 있는 것으로 나타났다 $[18,19]$. 마키베 리 추출물은 독성이 없는 추출물로서 항산화와 항염 효과가 우 수하며 퍼머넌트 시술 과정의 전처리, 중간, 후처리에 사용하였 을 때 모발 손상을 완화시키기는 것으로 관찰되었으며 또한, 조 추출물이 피부세포에 대해서 항산화 효과가 있고 황색포도상구 균과 녹농균 등의 균주에 대해서도 항균 효과가 있다는 연구도 있다[20,21].

기존에 진행되었던 마키베리에 대한 많은 연구는 식품의 측 면에서 효과가 있는지 여부에 집중되어 있다. 마키베리의 다양 한 활성성분이 화장품 원료로서 가능성이 있는지에 대한 좀더 구체적이고 다양한 연구는 미비한 상황이다. 따라서 본 연구에 서는 화장품의 원료로서 가능성에 집중하여 살펴보고자, 마키베 리를 에탄올로 1 차 추출하고 이를 3 가지 용매로 분획한 후 인 간 유래의 피부각질 세포주 $(\mathrm{HaCaT})$ 에 대한 항산화 효과와 멜 라닌색소 침착 세포주(B16F10)에 대한 미백 효과를 조사하였다. 또한, 4 가지 박테리아 균주들을 이용하여 항균 효과를 24 시간 동안 추적하여 방부제로서의 가능성도 타진해 보고자 하였다.

\section{재료 및 방법}

\section{실험 재료}

본 연구에서 사용된 마키베리(Maqui Berry, Chile)는 2016년에 페루에서 재배된 것을 약초판매업체인 두손애약초를 통해 2017 년에 동결건조 분말의 형대로 구입하였다. 시료의 효능을 알아 보기 위해 한국세포주은행(Korea Cell Line Bank, Seoul, Korea)에서 분양받은 $\mathrm{HaCaT}$ cell (keratinocyte)과 $\mathrm{B} 16 \mathrm{~F} 10$ cell (melanoma cell)을 이용하여 세포실험을 진행하였다. 세포들은 Dulbecco's modified Eagle's medium (DMEM; Hyclone ${ }^{\mathrm{TM}}$, GE Healthcare Life Sciences, Logan, UT, USA) 배지에 10\% 우태아혈청(FBS, Fetal Bovine Serum, Hyclone ${ }^{\mathrm{TM}}$, GE Healthcare Life Sciences)과 $1 \%$ 항생제 $(\mathrm{AB}$, Antibiotics, Hyclone $^{\mathrm{TM}}$, GE Healthcare Life Sciences)를 첨가한 영양배지로 incubator $\left(37^{\circ} \mathrm{C}, 5 \% \mathrm{CO}_{2}\right)$ 에서 배양하였다. 세포 세척에는 Phosphate buffered saline (PBS; Hyclone ${ }^{\mathrm{TM}}$, GE Healthcare Life Sciences)가 사용되었다. 시료의 독성을 알아보기 위해서 MTS assay (3-(4,5-dimethylthiazol-2-yl)-5-(3-carboxymethoxyphenyl)2-(4-sulfophenyl)-2H-tetrazolium, inner salt)를 시행하였고 CellTiter 96 ${ }^{\circledR}$ AQueous One Solution Cell Proliferation Assay (Promega, Madison, WI, USA)를 통해 진행하였다. 시료의 세포에 대한
안전성을 확인한 후 항산화 실험을 시행하였는데 2',7'-dichlorofluorescin diacetate (DCFDA) Cellular Reactive Oxygen Species (ROS) Detection Assay Kit (Abcam, Bristol, UK)로 진행하였다. 양성대조군은 glutathione (Sigma-Aldrich, St. Louis, MO, USA)을 사용하였다. 멜라닌 합성 저해 실험은 $\alpha$ MSH (Simga-Aldrich)를 처리하여 진행하였다. 그리고 Arbutin (Simga-Aldrich)을 양성대조군으로 이용하여 효과 정도를 관찰 하였다. 항균 실험에 사용된 박테리아에는 Staphylococcus aureus (S. aureus, KCTC 1927; Korean Collection for Type Cultures, Korea), Staphylococcus epidermidis (S. epidermidis, KCTC 1917; Korean Collection for Type Cultures, Korea), Pseudomonas aeruginosa (P. aeruginosa, KCTC 2004; Korean Collection for Type Culture, Korea), Escherichia coli (E. coli, KCTC 2571; Korean Collection for Type Culture, Korea) 등이 있는데 이를 Luria-Bertai (LB) 액체 배지에 접종 한 뒤 shaking incubator $\left(37^{\circ} \mathrm{C}, 200 \mathrm{rpm}\right)$ 에서 배양하였다. $\mathrm{LB}$ 배지의 조성은 $1 \mathrm{~L}$ 기준으로 증류수 $950 \mathrm{~g}$, sodium chloride (NaCl; Sigma-Aldrich) $10 \mathrm{~g}$, tryptone (BD Biosciences, Franklin Lakes, NJ, USA) $10 \mathrm{~g}$, yeast extract (Duchefa Biochemie, Haarlem, Netherlands) $5 \mathrm{~g}$ 이다. 그 외 ethanol, ethyl-acetate, chloroform, dimethyl sulfoxide (DMSO), hydrogen peroxide $\left(\mathrm{H}_{2} \mathrm{O}_{2}\right)$ 등은 대정화금의 1급 시약을 사용하였다.

\section{기기}

본 연구에서 사용된 기기에는 auto clave (DAE HAN BIO LINK Co., Ltd., Eumseong, Korea), $\mathrm{CO}_{2}$ incubator (MCO175; SANYO Electric Co., Ltd., Osaka, Japan), shaking incubator (VS-8480SF; Vision Scientific Co., Ltd., Daejeon, Korea), rotary evaporator (Rotavapor R-114; BÜCHI AG, Flawil, Switzerland), micro high speed centrifuge (Micro 17TR; Hanil Science Industrial Co., Ltd., Gimpo, Korea), centrifuge (Union 32R; Hanil Science Industrial Co., Ltd.), shaker (BF-350SK; Korea), microplate reader (Synergy HT; BioTek Instruments, Winooski, VT, USA) 등이 있다.

\section{시료의 추출}

본 연구의 시료인 동결 건조 분말인 마키베리 $100 \mathrm{~g}$ 에 $85 \%$ 에 탄올 $1 \mathrm{~L}$ 를 더한 후 빛을 차단하여 $24 \mathrm{~h}$ 동안 보관하고 이를 감압 여과와 농축 과정을 걸쳐 추출물을 얻었다. 이를 3 회 반 복하고 얻은 물질을 1 차 추출물로 하였다. 1 차 추출물에 클로 로포름 $\left(\mathrm{CHCl}_{3}\right)$ 과 증류수 $(\mathrm{DW})$ 를 $300 \mathrm{~mL}$ 씩 가한 후 분획 깔때

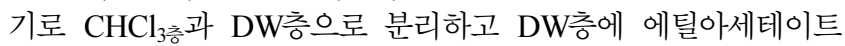
$(\mathrm{EtOAc})$ 를 $300 \mathrm{~mL}$ 더해 다시 분획을 시행하여 $\mathrm{EtOAc}$ 층과 $\mathrm{DW}$ 층을 얻었다.

\section{세포 생존율(Cell viability) 실험}

$\mathrm{HaCaT}$ cell과 $\mathrm{B} 16 \mathrm{~F} 10$ cell을 각각 96 well plate에 $1.5 \times 10^{4}$ cells/well으로 분주하고 incubator $\left(37^{\circ} \mathrm{C}, 5 \% \mathrm{CO}_{2}\right)$ 에서 $24 \mathrm{~h}$ 동안 배양하였다. DMSO에 분획된 추출물을 용해한 후 10,20 , $40 \mu \mathrm{g} / \mathrm{mL}$ 의 농도로 세포에 처리하고 incubator에서 $24 \mathrm{~h}$ 동안 배양하였다. 배지가 있는 상태에서 MTS시약을 $20 \mu \mathrm{L}$ 씩 더하고 $3 \mathrm{~h}$ 동안 incubator에 보관하면서 formazan의 상태를 관찰한 후 
microplate reader의 흡광도 모드 $495 \mathrm{~nm}$ 에서 값을 구하였다. Cell viability 값은 대조군에 대한 시료 처리군들의 흡광도 차 이를 백분율로 나타내었다.

Cell viability $(\%)=(\mathrm{A} / \mathrm{B}) \times 100$

$\mathrm{A}$ : 시료 처리군의 흡광도

$\mathrm{B}$ : 시료 무처리된 DMSO 용매 대조군 흡광도

\section{항산화 효능 실험}

$\mathrm{HaCaT}$ cell을 96 well plate에 $1.5 \times 10^{4}$ cells/well로 분주한 후 incubator에서 $24 \mathrm{~h}$ 동안 배양하였다. PBS로 2회 세척하여 phenol red를 제거한 후 $20 \mu \mathrm{M}$ 의 DCFDA를 well마다 처리한 다음 $45 \mathrm{~min}$ 간 incubator에서 보관하였다. $\mathrm{PBS}$ 로 다시 세척하 고 $500 \mu \mathrm{M} \mathrm{H} \mathrm{H}_{2} \mathrm{O}_{2}$ (hydrogen peroxide)와 $10,20,40 \mu \mathrm{g} / \mathrm{mL}$ 농도의 시료 추출물을 더한 후 $45 \mathrm{~min}$ 동안 다시 incubator에서 보관하였다. Microplate reader의 $485 / 528 \mathrm{~nm}$ 에서 형광값을 구 하여 대조군에 대한 시료 처리군들의 값을 계산하고 이를 백분 율로 나타내었다.

Relative activity $(\%)=(\mathrm{A} / \mathrm{B}) \times 100$

$\mathrm{A}$ : 시료 처리군의 형광값

$\mathrm{B}$ : 시료 무처리된 DMSO 용매 대조군 형광값

\section{멜라닌 합성 저해 효과 실험}

$\mathrm{B} 16 \mathrm{~F} 10$ cell을 6 well에 $1 \times 10^{5}$ cells/well로 분주한 다음 incubator에서 $24 \mathrm{~h}$ 동안 배양하였다. 대조군 외의 시료 처리군 들에 $\alpha$-MSH (100 nM)를 용해한 DMEM (serum free)을 30 $\min$ 동안 처리하였다. 배지를 교체하지 않고 시료 처리군들에 시료를 $2 \mathrm{X}$ 로 더한 후 incubator에서 $48 \mathrm{~h}$ 동안 배양하였다. 각 well의 배지를 제거하고 PBS로 세척한 다음 세포를 원심분리 $\left(4{ }^{\circ} \mathrm{C}, 12,000 \mathrm{rpm}, 3 \mathrm{~min}\right)$ 하였다. 상층액을 제거한 후 세포 pellet에 RIPA lysis buffer (Tris- $\mathrm{HCl}$ (pH 7.5) $50 \mathrm{mM}$, NP$401 \%, \mathrm{NaCl} 50 \mathrm{mM}$, SDS $0.1 \%$, sodium deoxycholate $0.5 \%$, protease inhibitor cocktail (Roche, Basel, Switzerland)) 를 처리하고 ice box에서 $30 \mathrm{~min}$ 간 보관하였다. 이를 다시 원 심분리 $\left(4^{\circ} \mathrm{C}, 14,000 \mathrm{rpm}, 10 \mathrm{~min}\right)$ 한 다음 상층액을 제거하여 pellet만 남겨 $60{ }^{\circ} \mathrm{C}$ oven에서 건조시켰다. 건조된 pellet에 $20 \%$ $\mathrm{DMSO}$ 와 $2 \mathrm{~N} \mathrm{NaOH} 200 \mu \mathrm{L}$ 를 첨가하여 섞어주고 $60{ }^{\circ} \mathrm{C}$ oven 에서 pellet을 용해시켰다. 용해물을 96 well에 $100 \mu \mathrm{L}$ 씩 담고 microplate reader의 $405 \mathrm{~nm}$ 에서 흡광도를 측정하였다.

Relative activity $(\%)=(\mathrm{A} / \mathrm{B}) \times 100$

$\mathrm{A}$ : 시료 처리군의 흡광도

$\mathrm{B}$ : 시료 무처리된 $\mathrm{DMSO}$ 용매 대조군 흡광도

\section{항균 활성 실험}

액체 배지(LB 배지)를 시험관에 $5 \mathrm{~mL}$ 씩 담고 Auto clave에서 멸균하였다. 균주들은 $24 \mathrm{~h}$ 동안 액체 배지에서 배양된 후 이를 고체 배지에 처리하여 $24 \mathrm{~h}$ 동안 다시 배양하고 그 중에서 single strain를 따서 액체 배지에서 $18 \mathrm{~h}$ 동안 배양하여 얻었다. 멸균 처리된 시험관 마다 배양된 균주들을 $5 \mu \mathrm{L}$ 씩 처리하였다. 시료들은 $0.1,0.2,0.5 \mathrm{mg} / \mathrm{mL}$ 의 농도로 처리되었다. 처리된 균
주와 시료를 고루 섞은 후 시험관의 배지를 $100 \mu \mathrm{L}$ 씩 96 well 에 담고 microplate reader의 $600 \mathrm{~nm}$ 에서 $0 \mathrm{~h}$ 의 흡광도 값을 측 정하였다. 시험관들은 shaking incubator에서 보관하고 접종한 균주가 성장하는 $6 \mathrm{~h}$ 부터 $3 \mathrm{~h}$ 간격으로 $24 \mathrm{~h}$ 동안 흡광도를 측 정하였다. 항균 효과는 $0 \mathrm{~h}$ 의 대조군 흡광도에 대한 각 시간대 별 시료 처리군들의 흡광도로 나타내어 농도와 시간대별에 대 한 변화를 관찰할 수 있었다. 측정된 흡광도 값을 대조군 값에 대해 계산하되, 시료들의 색채값을 제한 값을 효과값으로 하였다.

Relative activity $(\%)=\left(\mathrm{A}_{\mathrm{t}}-\left[\mathrm{A}_{0}-\mathrm{B}_{0}\right] / \mathrm{B}_{0}\right) \times 100$

$\mathrm{A}_{\mathrm{t}}$ : 시료 처리군(균 접종 후 시간별 상태)의 흡광도

$\mathrm{B}_{0}$ : 시료 무처리된 DMSO 용매 대조군의 흡광도 $(0 \mathrm{~h})$

$\mathrm{A}_{0}$ : 시료 처리군(균이 없는 상태)만의 흡광도 $(0 \mathrm{~h})$

\section{통계 분석}

본 실험들은 3회 이상 반복하여 실시하였다. 그래프는 각 실험 들의 횟수에 따르는 평균(mean)과 표준편차(standard deviation) 를 통해서 나타내었으며 유의성은 student's t-test로 검증하고 유 의미한 판정 범위를 $p<0.05(*<0.05, * *<0.01, * * *<0.001)$ 으로 정하였다.

\section{결과 및 고찰}

\section{세포 생존율}

마키베리 추출물들이 $\mathrm{HaCaT}$ cell과 $\mathrm{B} 16 \mathrm{~F} 10$ cell에 대해 항산 화 효과와 멜라닌 합성 저해 효과가 있는지를 알아보기 위한 실험을 하기 전에 추출물들의 세포들에 대한 독성 여부를 알아 보았다. 그 결과, 마키베리 $\mathrm{CHCl}_{3}$ 층과 $\mathrm{EtOAc}$ 층, $\mathrm{DW}$ 층의 추출 물들은 $\mathrm{HaCaT}$ cell의 생존에 영향을 주지 않았고 $\mathrm{B} 16 \mathrm{~F} 10$ cell 도 마키베리 추출물들을 처리하였을 때, 대조군 $(100 \%)$ 에 비해 생존율이 높게 나타났다. 이에 $\mathrm{HaCaT}$ cell과 $\mathrm{B} 16 \mathrm{~F} 10$ cell의 생 존율 실험에 사용되었던 마키베리 추출물들의 농도와 동일한 농 도인 $10,20,40 \mu \mathrm{g} / \mathrm{mL}$ 의 농도로 항산화와 멜라닌 합성 저해 효과 실험을 진행하였다(Fig. 1).

본 연구의 결과는 Kang[20]과 Jung의 연구[21]에서 마키베리 조추출물이 세포독성을 보이지 않았다는 결과와 일치하였고 이 를 통해서 마키베리가 안전한 천연물일 것으로 판단되었다.

\section{항산화 효과}

마키베리 추출물들이 항산화 효과가 있는지를 알아본 결과, 각 질형성세포인 $\mathrm{HaCaT}$ cell에 대해 추출물들이 농도의존적으로 항산화 효과를 보였다(Fig. 2). 특히, $\mathrm{EtOAc}$ 층 추출물들이 산화 스트레스에 우수한 효과가 있는 것으로 확인되었는데 $\mathrm{H}_{2} \mathrm{O}_{2}$ 대 조군(100\%)에 비해 산화스트레스가 $53-55 \%$ 감소되었다. DW층 과 $\mathrm{CHCl}_{3}$ 층 추출물들도 산화스트레스를 각각 $36-54 \%, 36-47 \%$ 감소시켰다. 본 결과를 통해서 판단할 때, 마키베리 추출물들이 양성대조군인 glutathione $(58 \%)$ 과 항산화 능력이 유사할 정도 로 우수한 항산화 물질인 것으로 생각된다.

항산화 효과에 대한 기존의 연구 중에 Jung의 연구[21]에서 마키베리 $99 \%$ 에탄올 조추출물 $50,100 \mu \mathrm{g} / \mathrm{mL}$ 농도에서 농도 의존적으로 항산화 효과가 나타났다고 했다. 이는 본 연구에서 


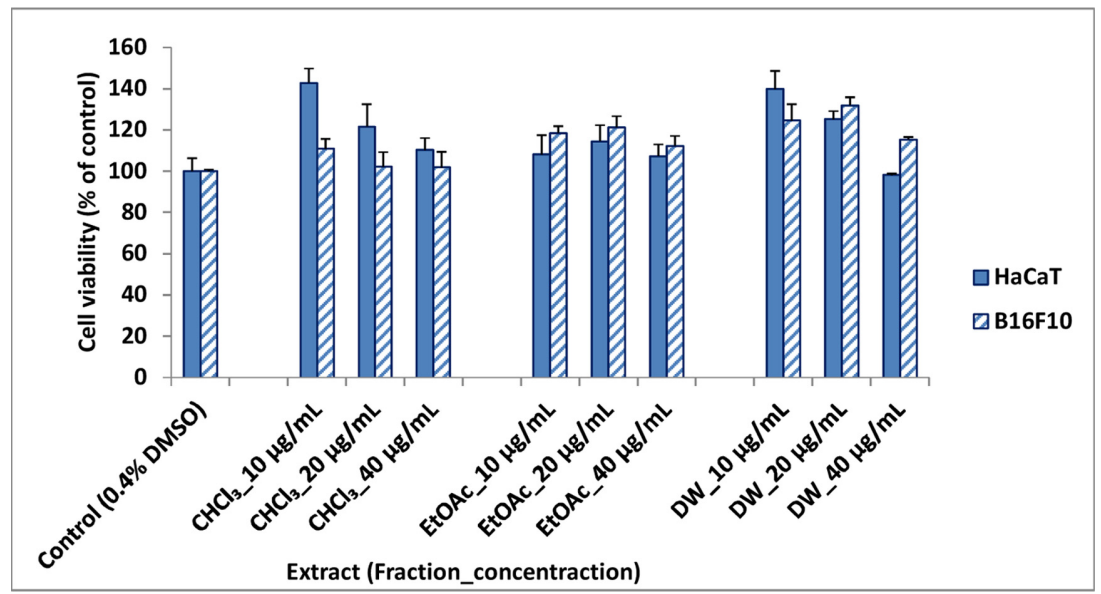

Fig. 1 The chloroform $\left(\mathrm{CHCl}_{3}\right.$ ), ethyl acetate (EtOAc) and distilled water (DW) fractions of Aristotelia chilensis (10, 20, or 40 $\left.\mu \mathrm{g} / \mathrm{mL}\right)$ showed no significant cytotoxicity toward HaCaT human keratinocyte and B16F10 mouse melanoma cells

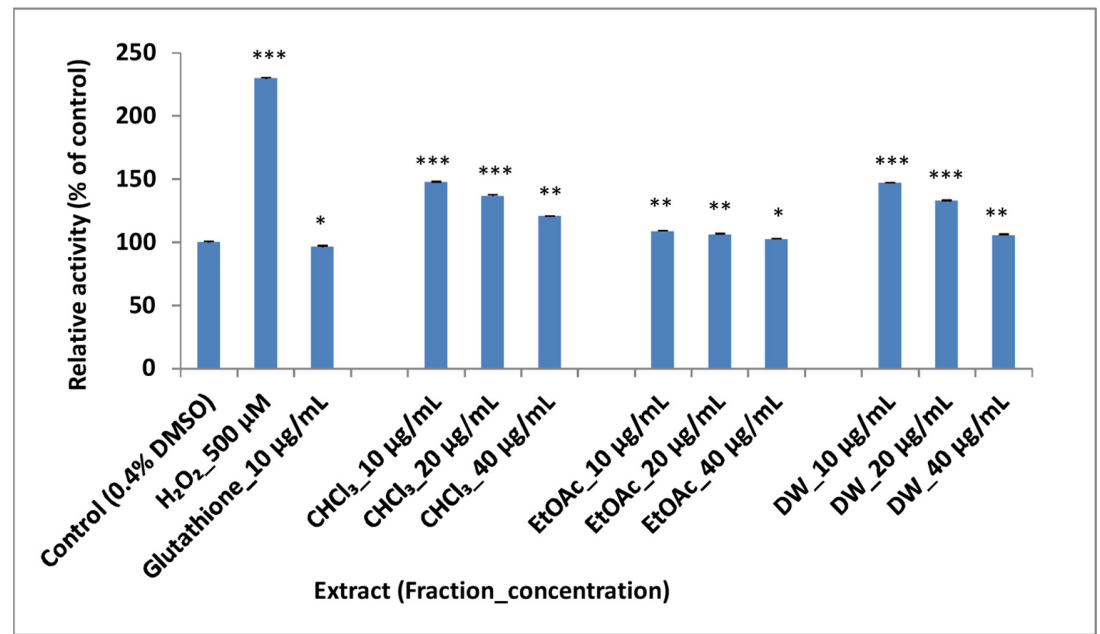

Fig. 2 The chloroform $\left(\mathrm{CHCl}_{3}\right.$ ), ethyl acetate (EtOAc) and distilled water (DW) fractions of Aristotelia chilensis (10, 20, or 40 $\left.\mu \mathrm{g} / \mathrm{mL}\right) \mathrm{reduced}$ oxidative stress in $\mathrm{H}_{2} \mathrm{O}_{2}$-treated cells in a dose-dependent manner. Values represent mean $\pm \mathrm{SD}$ of three independent experiments $\left({ }^{*} p<0.05,{ }^{* *} p<0.01\right.$, $* * * p<0.001)$

분획한 3가지 층의 마키베리 추출물이 모든 농도에서 우수한 항산화 효과가 나타난 것과 일치한 결과이다. 덧붙여, 분획할 경우 낮은 농도에서도 항산화 효과가 나타나는 것을 알 수 있 었다. 이는 3 가지 용매를 통해서 분획되면서 활성물질들이 분 리, 농축되었기에 낮은 농도에서도 항산화 효과가 나타난 것으 로 생각된다. 또한, Chung의 연구[14]에서는 $60 \%$ 마키베리 에 탄올 추출물이 아로니아, 블랙커런트에 비해 DPPH 및 ABTS radical 소거능, FRAP, 환원력에서 유의적으로 활성이 높았고 양 성 대조군인 ascorbic acid에 비해서도 우수하다고 하였다. 이는 본 연구에서 마키베리 EtOAc층 추출물이 glutathione $(10 \mu \mathrm{g}$ $\mathrm{mL}$ )에 비견할 만한 항산화 능력을 보인 것과 일치하였다. 이를 통해서 마키베리 추출물은 천연 항산화제로 활용할 수 있는 가 능성이 있는 원료로 생각된다.

\section{멜라닌 합성 저해 효과}

마키베리 추출물들이 멜라닌 합성을 저해하는지를 살펴본 결과,
마키베리 추출물들은 농도의존적으로 멜라닌 합성을 저해하였 다(Fig. 3). 그 중에서 EtOAc층 추출물들은 $\alpha-\mathrm{MSH}$ 를 처리한 대조군과 비교할 때, 멜라닌 합성을 각각 $26,34,39 \%$ 억제시 켰다. DW층 $40 \mu \mathrm{g} / \mathrm{mL}$ 도 멜라닌 합성을 $21 \%$ 억제시켰다. 마 키베리 EtOAc층은 양성대조군인 arbutin $(57 \%)$ 보다 억제 효과 가 우수하지는 않았지만 arbutin 측정 농도가 추출물의 농도에 비해 높은 것을 감안하면 멜라닌 합성을 저해하는데 효과가 있 는 것으로 판단된다.

멜라닌 합성 저해 효과에 대한 연구에서 Chung[14]은 마키 베리 추출물이 아로니아, 블랙커런트 추출물보다 Tyrosinase 저 해 활성이 낮다고 하였고 Park과 Hong[22]은 아로니아가 100$1000 \mu \mathrm{g} / \mathrm{mL}$ 의 농도에서 Tyrosinase 저해 활성이 우수하다고 보 고하였다. 본 연구의 마키베리 EtOAc층의 멜라닌 합성 저해 효 과 결과와 기존 연구를 비교하면 본 실험의 마키베리 EtOAc층 은 낮은 농도에서도 우수한 효과가 나타났고 이는 양성대조군 인 Arbutin $(250 \mu \mathrm{g} / \mathrm{mL})$ 에 비해서도 뒤지지 않았다. 따라서 마 


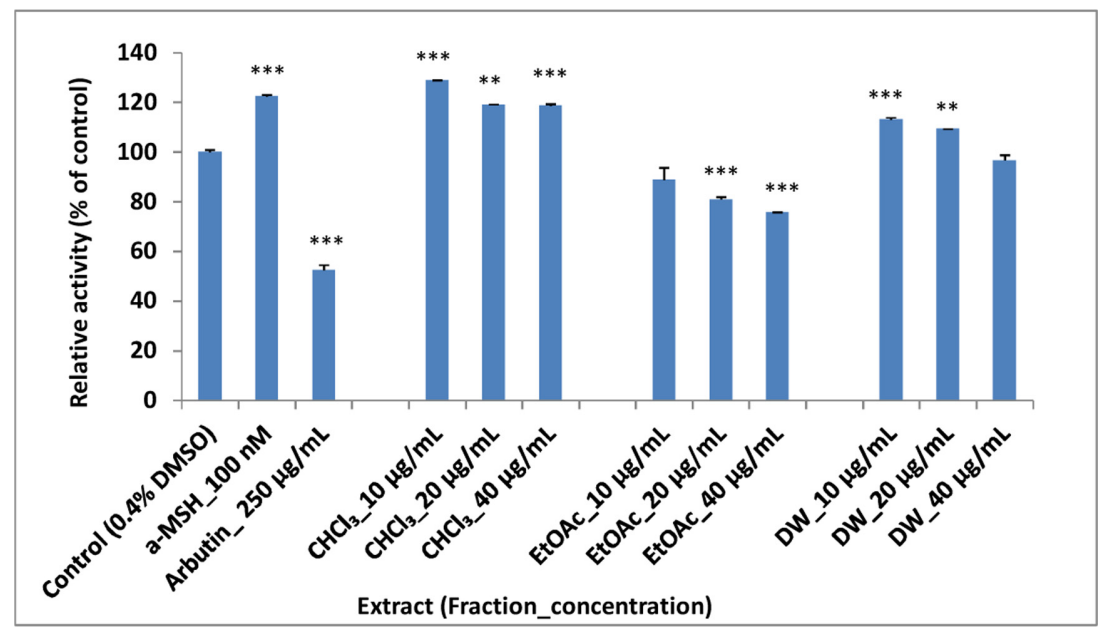

Fig. 3 The chloroform $\left(\mathrm{CHCl}_{3}\right.$ ), ethyl acetate (EtOAc) and distilled water (DW) fractions of Aristotelia chilensis $(10,20$, or $40 \mu \mathrm{g} / \mathrm{mL}) \mathrm{reduced}$ melanin synthesis in $\alpha$-MSH-treated cells. In particular, EtOAc fractions of A. chilensis kept the run of arbutin $(250 \mu \mathrm{g} / \mathrm{mL})$. Values represent mean $\pm \mathrm{SD}$ of three independent experiments $\left(* * p<0.01,{ }^{* * *} p<0.001\right)$
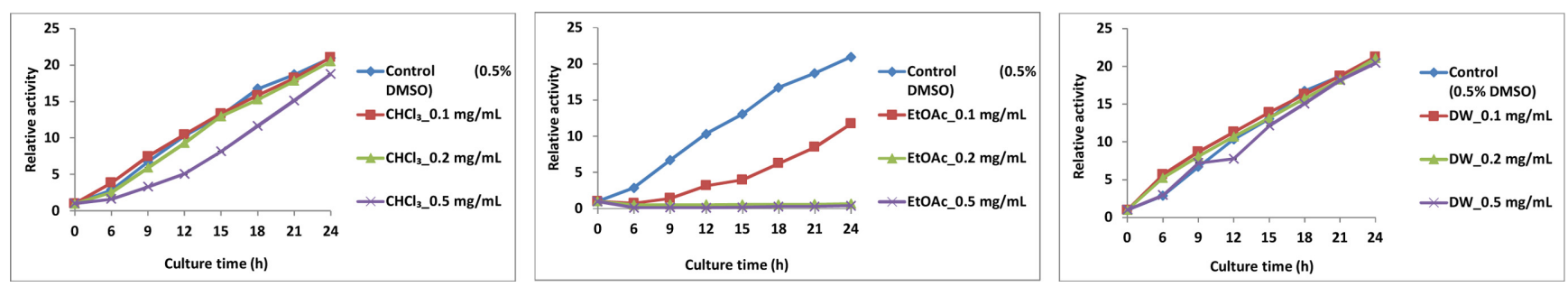

Fig. 4 The chloroform $\left(\mathrm{CHCl}_{3}, 0.5 \mathrm{mg} / \mathrm{mL}\right)$ and ethyl acetate (EtOAc) fractions $(0.1,0.2$, or $0.5 \mathrm{mg} / \mathrm{mL})$ of Aristotelia chilensis reduced the growth of Staphylococcus aureus (S. aureus). In particular, the EtOAc fractions exhibited high antibacterial activity

키베리 추출물은 미백화장품의 원료로 가능성이 있을 것으로 생 각된다.

\section{항균활성 효과}

마키베리 추출물들이 항균효과가 있는지를 알아보기 위해 4종 의 균주에 실험을 진행하였다. 그람양성균인 S. aureus, S. epidermidis과 그람음성균인 P. aeruginosa, E. coli에 마키베리 추출물들을 $0.1,0.2,0.5 \mathrm{mg} / \mathrm{mL}$ 로 처리하고 $3 \mathrm{~h}$ 간격으로 $24 \mathrm{~h}$ 동안의 항균 활성을 살펴 보았다. 마키베리 추출물들은 4 개의 균주 중에 S. aureus에 대해 뛰어난 항균 효과를 보였고 추출 물들 중에서도 $\mathrm{EtOAc}$ 층이 균주들에 대해 효과가 우수하였다. 먼저, 마키베리 EtOAc층 0.2 와 $0.5 \mathrm{mg} / \mathrm{mL}$ 은 관찰이 진행된 $24 \mathrm{~h}$ 동안 $S$. aureus 균의 증식을 저지하여 마키베리 추출물들 중에 항균 효과가 뛰어난 것으로 확인되었다. EtOAc층 $0.1 \mathrm{mg} /$ $\mathrm{mL}$ 도 대조군에 비해 균의 증식을 더디게 하여 관찰 $24 \mathrm{~h}$ 에서 도 $44 \%$ 의 항균 효과가 나타났다. 마키베리 $\mathrm{CHCl}_{3}$ 층에서도 농 도의존적 경향이 보였는데 $0.5 \mathrm{mg} / \mathrm{mL}$ 에서 항균 효과가 보였으 나 $\mathrm{CHCl}_{3}$ 층 $0.1,0.2 \mathrm{mg} / \mathrm{mL}$ 에서는 대조군과 유사한 경향이 나 타났다. DW층의 경우는 대조군과 같이 시간의 흐름에 따라 균 이 증식하여 항균 활성이 없는 것으로 확인되었다(Fig. 4).

마키베리 추출물들은 그람양성균인 S. epidermidis에 대해서 도 항균 효과를 보였다. 추출물들 중에서 $\mathrm{EtOAc}$ 층들이 다른 추
출물들과 달리 관찰 시간 동안 농도의존적으로 항균 효과를 보 였는데, 이 중에서 EtOAc층 $0.5 \mathrm{mg} / \mathrm{mL}$ 는 $24 \mathrm{~h}$ 에서 대조군에 비해 $72 \%$ 이상의 항균 활성이 관찰되었다. 마키베리 $\mathrm{CHCl}_{3}$ 층 에서는 $0.5 \mathrm{mg} / \mathrm{mL}$ 농도가 관찰 $18 \mathrm{~h}$ 까지 대조군에 비해 균의 증식을 더디게 하였으나 $\mathrm{CHCl}_{3}$ 층 $0.1,0.2 \mathrm{mg} / \mathrm{mL}$ 는 항균 활성 을 보이지 않았다. DW층도 항균 활성을 보이지 않았다(Fig. 5). 마키베리 추출물들은 그람음성균인 P. aeruginosa에 대해서도 항균 효과를 보였다. 추출물들 모두에서 항균 효과가 나타났는 데, 그 중에서 $\mathrm{EtOAc}$ 층들이 다른 추출물들보다 좀더 우수한 경 향성을 보였다. EtOAc층 $0.5 \mathrm{mg} / \mathrm{mL}$ 는 관찰 $24 \mathrm{~h}$ 에서 대조군에 비해 $54 \%$ 이상의 항균 활성을 보였고 $0.1,0.2 \mathrm{mg} / \mathrm{mL}$ 도 각각 $28,42 \%$ 의 항균 효과를 보였다. 마키베리 $\mathrm{CHCl}_{3}$ 층에서도 관찰 $24 \mathrm{~h}$ 동안 농도의존적으로 균의 증식이 저지되는 경향이 관찰 되었다. DW층의 농도들도 P. aeruginosa에 대해 미약하지만 항 균 효과를 나타냈다(Fig. 6).

마키베리 추출물들은 그람음성균인 E. coli에 대해서는 항균 효과를 나타내지 못하였다. 모든 추출물들에서 균의 증식이 대 조군과 유사하거나 보다 활발한 증식의 경향성을 보였다(Fig. 7). Genskowsky등의 연구[23]에서 키토산과 마키베리 추출물을 함 께 처리했을 때 그람양성균과 그람음성균에 대해서 항균 효과 를 보인다고 하였는데 본 연구 에서도 그람양성균인 S. aureus, S. epidermidis과 그람음성균인 P. aeruginosa에 대해 항균 효과 

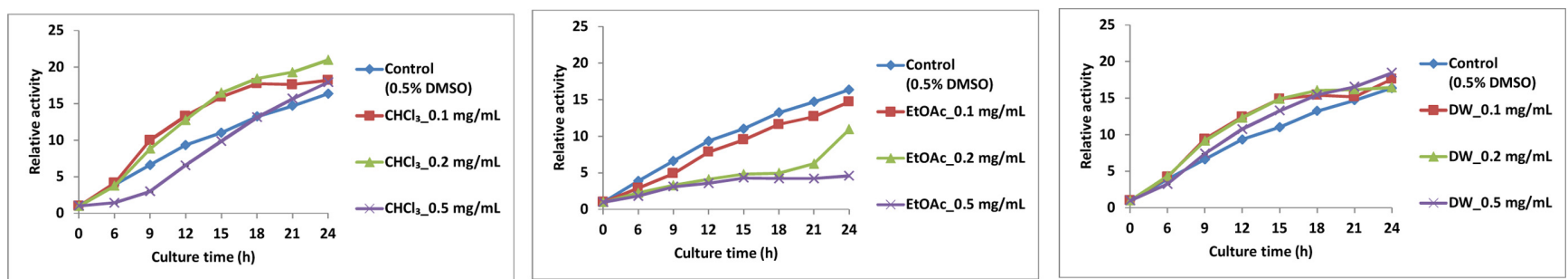

Fig. 5 The chloroform $\left(\mathrm{CHCl}_{3}, 0.5 \mathrm{mg} / \mathrm{mL}\right)$ and ethyl acetate (EtOAc) fractions $(0.1,0.2$, or $0.5 \mathrm{mg} / \mathrm{mL})$ of Aristotelia chilensis decreased the growth of Staphylococcus epidermidis (S. epidermidis)
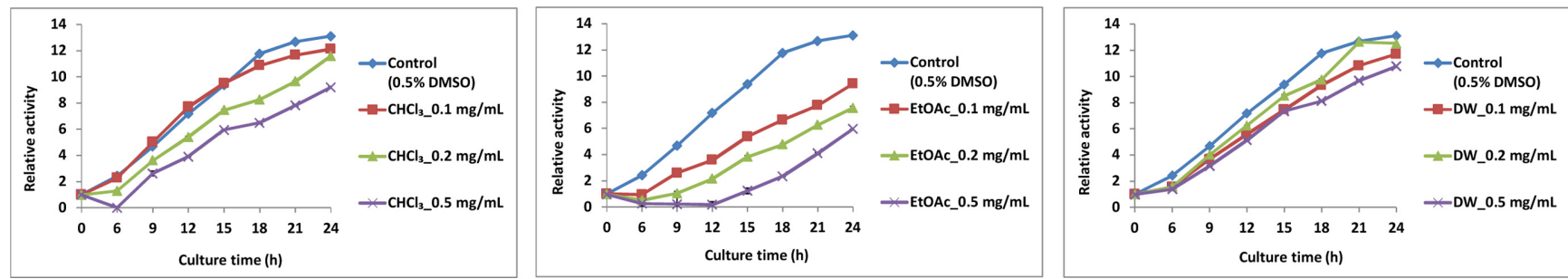

Fig. 6 The chloroform $\left(\mathrm{CHCl}_{3}\right)$, ethyl acetate (EtOAc) and distilled water (DW) fractions of Aristotelia chilensis $(0.1,0.2, \mathrm{or} 0.5 \mathrm{mg} / \mathrm{mL}) \mathrm{reduced}$ the growth of Pseudomonas aeruginosa (P. aeruginosa)
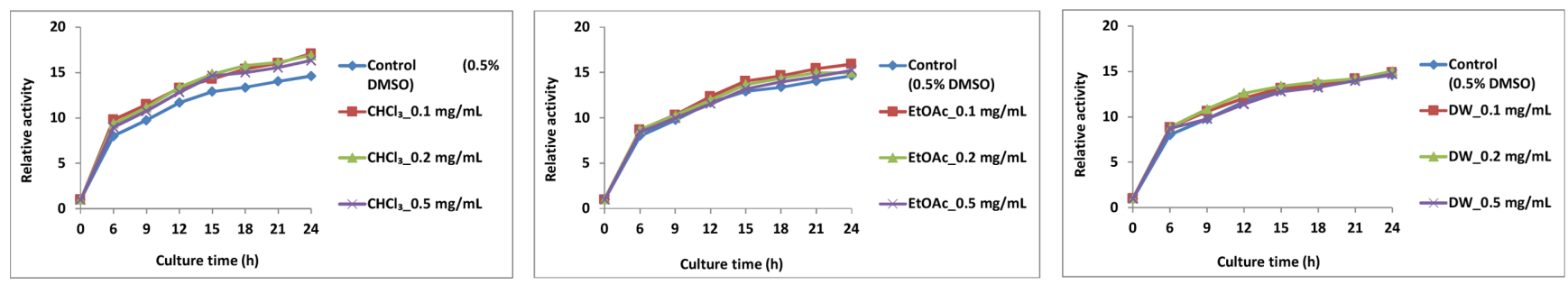

Fig. 7 The chloroform $\left(\mathrm{CHCl}_{3}\right)$, ethyl acetate (EtOAc) and distilled water (DW) fractions of Aristotelia chilensis $(0.1,0.2$, or $0.5 \mathrm{mg} / \mathrm{mL})$ did not reduce the growth of Escherichia coli (E. coli)

를 나타냈다. Jung의 연구[21]에서도 마키베리 추출물은S. aureus과 P. aeruginosa에 대해 항균력을 나타냈다고 하였다. 본 연구에서는 분획된 EtOAc층이 S. aureus에 대해 확연하게 항균 효과를 보여 마키베리의 성분 중에 $\mathrm{EtOAc}$ 층에 포함된 성분이 항균력을 나타내는데 관여하는 것으로 생각된다. 그러나, Nam 등의 연구[24]와 Puupponen-Pimia 등의 연구[25]에서 주로 그 람음성균에 대해 항균활성이 나타났다는 것과는 달리 본 연구 에서는 그람양성균에 대해 활성이 높게 나타났고 Nam 등의 연 구 결과 중에서 라즈베리와 크랜베리가 그람양성균인 S. aureus 에 대해 항균효과가 나타났다는 것과는 일치하였다. 기존의 결 과와 본 연구 결과를 통해서 마키베리가 천연항균제와 방부제 의 원료로서 화장품의 방부 효과를 높이고 나아가 식품의 부패 와 변질을 막을 수 있는 원료로 활용할 수 있을 것으로 생각된다.

\section{초 록}

본 연구는 마키베리 추출물이 화장품의 신규 원료로서 가능성 이 있는지를 타진하는 것을 목적으로 진행되었다. 마키베리 조 추출물을 클로로포름층과 에틸아세테이트층, 증류수층으로 분리
하였다. 먼저, 마키베리 추출물들의 독성 여부를 피부각질세포 주인 $\mathrm{HaCaT}$ 세포와 색소형성세포주인 $\mathrm{B} 16 \mathrm{~F} 10$ 세포를 통해 확 인하였다. 항산화 효과 실험에서 클로로포름층, 에틸아세테이트 층 그리고 증류수층 추출물들은 모두 산화적 스트레스를 줄이 는 효과를 보였고 그 중에 에틸아세테이트층 추출물은 양성대 조군인 글루타치온에 비해서도 우수한 결과를 나타내었다. 마키 베리 추출물들은 $\alpha-\mathrm{MSH}$ 에 의한 멜라닌 합성도 저해하였다. 또 한, 마키베리 추출물들은 그람양성균인 황색포도상구균과 표피 포도상구균, 그람음성균인 녹농균에 대해서도 항균 효과를 보였 다. 특히, 에틸아세테이트층 추출물은 황색포도상구균에 대해서 뛰어난 항균 효과를 보였다. 본 연구를 통해서 마키베리 추출 물들이 화장품의 항산화나 미백 기능성 원료로서뿐만 아니라 화 장품의 천연방부제 원료로서도 잠재적인 가능성이 있음을 확인 할 수 있었다.

Keywords 마키베리 - 멜라닌 합성 저해 - 항균 - 항산화 - 화 장품 신규 원료

감사의 글 본 연구는 동덕여자대학교 연구년 지원에 의해서 수행되었습니 다. 또한 본 연구는 한국연구재단의 일반연구연구비 지원(NRF2016 R1D1A1B03930171)에 의해서 수행되었습니다. 


\section{References}

1. Lim YY, Lim TT, Tee JJ (2007) Antioxidant properties of several tropical fruits: A comparative study. Food Chem 103: 1003-1008

2. Jeong CH, Jang CW, Lee KY, Kim IH, Shim KH (2012) Chemical components and anti-oxidant activities of black currant. Korean J Food Preserv 19: 263-270

3. Ko GA, Koh SY, Ryu J, Kim S (2017) Comparison of proximate compositions, antioxidant, and antiproliferative activities between blueberry and Sageretia thea (Osbeck) MC Johnst fruit produced in Jeju Island. J Appl Biol Chem 60: 161-171

4. Seeram NP, Adams LS, Zhang Y, Lee R, Sand D, Scheuller HS, Heber D (2006) Blackberry, black raspberry, blueberry, cranberry, red raspberry, and strawberry extracts inhibit growth and stimulate apoptosis of human cancer cells in vitro. J Agric Food Chem 54: 9329-9339

5. Lee Y, Lee JH, Kim SD, Chang MS, Jo IS, Kim SJ, Hwang KT, Jo HB, Kim JH (2015) Chemical composition, functional constituents, and antioxidant activities of berry fruits produced in Korea. J Korean Soc Food Sci Nutr 44: 1295-1303

6. Francis FJ (1982) Analysis of anthocyanins. In: Pericles M (ed) Anthocyanins as food colors, Academic Press, Inc. New York, pp 181207

7. Cai Y, Sun M, Corke H (2003) Antioxidant activity of betalains from plants of the Amaranthaceae. J Agric Food Chem 51: 2288-2294

8. Kim HB, Kim SY, Lee HY, Kim SL, Kang SW (2005) Protective effect against neuronal cell and inhibitory activity against bacteria of mulberry fruit extracts. Korean J Crop Sci 50(spc1): 220-223

9. Kim YH, Lee JH, Lee YS, Yun HT (2006) Antioxidant activity and extraction efficiency of anthocyanin pigments in black colored soybean. Korea Soybean Digest. 23: 1-9

10. Park YH, Chang SK (2000) Effects of shikonin pigments from the roots of Lithospermum erythrorhizon on rabbit platelets. J Fd Hyg Safety 15: 167-172

11. Park YH, Lee CS (2011) Efficacy of safflower on the acne skin and its application for facial cleansing biomedical material. J Korean Chem Soc 55: 400-404

12. Bagchi D, Sen CK, Bagchi M, Atalay M (2004) Anti-angiogenic, antioxidant, and anti-carcinogenic properties of a novel anthocyanin-rich berry extract formula. Biochemistry (Mosc) 69: 75-80

13. Prado CHB, Damascos MA (2001) Gas exchange and leaf specific mass of different foliar cohorts of the wintergreen shrub Aristotelia chilensis
(Mol.) Stuntz (Eleocarpaceae) fifteen days before the flowering and the fall of the old cohort. Braz Arch Biol Technol 44: 277-282

14. Chung HJ (2016) Comparison of bioactive constituents and biological activities of aronia, blackcurrant, and maquiberry. J Korean Soc Food Sci Nutr 45: 1125-1129

15. Lee KW, Je H, Jung TH, Choi JH, Hwang HJ, Shin KO (2018) Comparison of Components and Antioxidant Activity of Cherry, Aronia, and Maquiberry. Korean J Food Nutr 31: 729-736

16. Nahuelhual L, Carmona A, Lara A, Echeverría C, González ME (2012) Land-cover change to forest plantations: Proximate causes and implications for the landscape in south-central Chile. Landsc Urban Plan 107: $12-20$

17. González B, Vogel H, Razmilic I, Wolfram E (2015) Polyphenol, anthocyanin and antioxidant content in different parts of maqui fruits (Aristotelia chilensis) during ripening and conservation treatments after harvest. Ind Crop Prod 76: 158-165

18. Céspedes CL, El-Hafidi M, Pavon N, Alarcon J (2008) Antioxidant and cardioprotective activities of phenolic extracts from fruits of Chilean blackberry Aristotelia chilensis (Elaeocarpaceae), Maqui. Food Chem 107: 820-829

19. Rojo LE, Ribnicky D, Logendra S, Poulev A, Rojas-Silva P, Kuhn P, Dorn R, Grace MH, Lila MA, Raskin I (2012) In vitro and in vivo antidiabetic effects of anthocyanins from Maqui Berry (Aristotelia chilensis). Food Chem 131: 387-396

20. Kang EJ (2016) Hair Protection Effects according to the Time of Aristotelia chilensis Extract Applied during Setting Perm. Dissertation, University of Wonkwang

21. Jung HJ (2016) A Study on Antibacterial and Anti-oxidative effects of Maqui Berry Extracts. Dissertation, University of Dongduk Women's

22. Park HM, Hong JH (2014) Physiological activities of Aronia melanocarpa extracts on extraction solvents. Korean J Food Preserv 21: 718-726

23. Genskowsky E, Puente LA, Pérez-Álvarez JA, Fernandez-Lopez J, Muñoz LA, Viuda-Martos M (2015) Assessment of antibacterial and antioxidant properties of chitosan edible films incorporated with maqui berry (Aristotelia chilensis). LWT-Food Sci Technol 64: 1057-1062

24. Nam JS, Han YJ, Yeo SM (2015) Antioxidant and antimicrobial activities of various berry juices. Korean J Food Nutr 28: 328-334

25. PuupponenPimiä R, Nohynek L, Meier C, Kähkönen M, Heinonen M, Hopia A, OksmanCaldentey KM (2001) Antimicrobial properties of phenolic compounds from berries. J appl microbiol 90: 494-507 